\title{
ORGANIZATION OF WAPELLO AND MONROE COUNTIES.
}

The Fifth Territorial Legislature in 1843 established and defined the boundaries of new counties in the lands then recently ceded by the Sac and Fox Indians. Two of these, Wapello and Kishkekosh, the latter now Monroe, were attached for judicial, revenue and election purposes to Jefferson county. It was the duty of the county commissioners of Jefferson county to have the boundaries of these new counties surveyed and marked.

The county commissioners of Jefferson county in 1843 were E. J. Gilham, B. S. Dunn and Thomas Mitchell. At a special session on April 18th they "ordered that David Switzer be authorized and he is hereby appointed to employ five good and sufficient hands to carry chain, mark, blaze, \&c., and a teem of cattle or horses, sufficient for the conveyance of the necessary tools, provisions, \&c., and to proceed (in pursuance of an Act of the Iowa Legislature) to survey and mark out the boundary lines of the new counties west of Jefferson, which are to be attached to Jefferson for judicial, election and revenue purposes; and that the hands thus employed be allowed for their services per day each $\$ 1.50$; and that the said Switzer be authorized to make out and present to this board a reasonable bill for his own services, including the expense of teem, provisions, \&c."

On August 21st the return of the survey was accepted and the fee bill allowed. This shows "the hands" were Andrew Kenedy, Samuel Allender, Stephen Cooper, James Chandler and Jonathan 'Turner, who furnished the "teem". They. were out twenty-four days. Turner was paid seventy-two dollars, the other men thirty-six dollars each. Switzer received seventy-five dollars for twenty-five days. The cost of "boarding" was thirty-two dollars and fifty cents. One dollar went to Martin Tucker for "ferriage".

The total expense of the expedition was $\$ 324.50$, which was divided among the three counties according to their respective interests, Jefferson paying $\$ 67.60$, Wapello $\$ 108.17$, and Kishkeḳosh \$148.73. 
On this same date were appointed the judges of election in the two counties for the election to be held on the second Tuesday in October. Wapello county had four voting places. One was at the house of Thomas Ping; one at the town of Dahlonega; one at Eddyville, and one at the town of Ottumwa. The judges named to serve at Ping's were Silas Garrison, D. G. Laforce and S. M. Wright, at Dahlonega, Edward Haggard, Josiah M. Knight and Peter White; at Eddyville, William R. Ross, H. Workman and Robert Newell, and at Ottumwa, William Dewey, J. Barnett and James Payne.

Kishkekosh county had but one voting place. This was at Clark's Point. The judges named to serve there were James Myers, Wareham Clark and Hardin Smith.

Such is the record, as it has been preserved, of the authority exercised by Jefferson county over the counties of Wapello and Kishkekosh during their period of organization.

C. J. F.

THE DISCOVERY AND INTERMENT OF THE REMAINS OF JOEL HOWE, A VICTIM OF THE SPIRIT LAKE MASSACRE.

In July, 1914, a young man in the summer camp of the Iowa Young Men's Christian Association on their property on the east shore of East Okoboji lake, discovered remains he thought to be of a human being. Mr. Harry Goodrich, in charge of the camp, directed a thorough search, took possession of all that was recovered, and reported to the Curator of the Historical Department of Iowa.

On August 4th the Curator, in company with survivors of the Spirit Lake expedition, Roderick A. Smith, Guernsey Smith, J. N. Maxwell, A. H. Malcom and some ten or twelve others visited the spot where the bones were discovered. There was noted at the time and place the following:

The remains were discovered about eighteen inches below the present level of the soil. The former surface of the ground apparently is thus modified: 
Copyright of Annals of Iowa is the property of State of Iowa, by \& through the State Historical Society of Iowa and its content may not be copied or emailed to multiple sites or posted to a listserv without the copyright holder's express written permission. However, users may print, download, or email articles for individual use. 